\title{
Multiple Receptor Systems Promote CNS Neural Migration
}

\author{
Renata B. Fishman and Mary E. Hatten \\ Rockefeller University, New York, New York 10021
}

To identify glial receptor systems in CNS migration, cerebellar granule neuron migration was assayed on glass fibers coated with polylysine, astroglial membranes (AM fibers), or the extracellular matrix proteins collagen (COLL fibers), fibronectin (FN fibers), and laminin (LAM fibers). By video microscopy, granule cells migrated along AM fibers with the cytology, neuron-fiber apposition, and dynamics seen on living glia. The demonstration that immobilized astroglial membranes support neural migration suggests that astroglial receptor systems, in combination with glial fiber geometry, promote CNS neural migration. Moreover, granule neurons migrated rapidly on LAM fibers, moved relatively slowly on FN fibers, and not at all on COLL fibers. Antibody perturbation analyses suggested that, whereas astrotactin provides the neural receptor for migration on astroglial membranes, integrin $\beta 1$ provides the neural receptor for migration on LAM fibers. These results suggest that multiple receptor systems support CNS neural migration.

[Key words: neuronal migration, astroglia, extracellular matrix, cerebellum, neural development, granule cell]

One of the critical questions in cortical histogenesis is the control of neural migrations in developing brain. Although a system of radial glial fibers has been shown to provide the primary pathway for CNS neuronal migrations, guiding postmitotic neurons from proliferative zones out through the thickening wall of the anlage (Rakic, 1971, 1972; Sidman and Rakic, 1973; Misson et al., 1991), the glial receptor systems that promote migration have not been identified. Among brain regions, neural migrations in the cerebellar cortex have been the most intensively analyzed, the migration of cerebellar granule neurons along Bergmann glial fibers providing the best studied example of gliaguided neural migration, by in vivo Golgi (Ramon y Cajal, 1889, 1911), electron microscopic (Rakic, 1971), ${ }^{3} \mathrm{H}$-thymidine labeling (Miale and Sidman, 1961), genetic (Rakic and Sidman, 1973; Sotelo and Changeux, 1974), and in vitro studies (Hatten et al., 1984; Hatten, 1990). Time-lapse, video-enhanced, differential-contrast microscopic studies of the migration of living granule cells along single glial fibers in real time (Hatten et al., 1984; Edmondson and Hatten, 1987; Hatten and Mason, 1990) reveal that neuronal migration is a specialized form of cell mo-

\footnotetext{
Received Nov. 2, 1992; revised Feb. 18, 1993; accepted Feb. 25, 1993.

We are grateful to our colleagues Drs. Carol Mason, Gord Fishell, Rodolfo Rivas, Susana Vidan, and W. Q. Gao for helpful discussions. We thank Dr. Randal Streck for his expert assistance with autoradiography, and Ray Manson for preparation of photographs. This work was supported by NIH Grant NS 15429 (M.E.H.) and a Muscular Dystrophy Association postdoctoral fellowship (R.F.).

Correspondence should be addressed to Mary E. Hatten, Rockefeller University, 1230 York Avenue, New York, NY 10021.

Copyright (C) 1993 Society for Neuroscience $0270-6474 / 93 / 133485-11 \$ 05.00 / 0$
}

tility that requires the formation of an extensive, interstitial junction along the apposition between the neural soma and the glial fiber and the extension of a leading process that enfolds the glial fiber as the neuron moves (Edmondson and Hatten, 1987; Gregory et al., 1988; Hatten and Mason, 1990; Rivas et al., 1991).

The formation of a specialized, interstitial junction with the glial fiber along the neural soma, and of punctae adherentia with the glial fiber along the leading process of migrating neurons (Hatten et al., 1984; Gregory et al., 1988), has suggested that cell surface receptor systems provide a molecular basis for migration. Antibody perturbation analyses of cerebellar granule cell migration in vitro indicate that among the neural cell adhesion systems N-CAM, L1, TAG- 1 , integrin $\beta 1$, and the neural glycoprotein astrotactin, astrotactin provides a neural receptor system for migration (Fishell and Hatten, 1991). Anti-astrotactin antibodies block the binding of neuronal membranes to astroglial cells (Stitt and Hatten, 1990) and inhibit the migration of granule neurons along astroglial fibers in vitro (Fishell and Hatten, 1991). Expression of the major component of the astrotactin activity, a cell surface glycoprotein with an apparent molecular weight of approximately $100 \mathrm{kDa}$ (Edmondson et al., 1988), is maximal during the period of granule cell migration and assembly into the internal granule cell layer of the cerebellar cortex in vivo (R. B. Fishman and M. E. Hatten, unpublished observations). By immunolabeling, astrotactin is not expressed by astroglial cells, suggesting that astrotactin binds to a heterotypic, glial adhesion system.

In addition to cell surface receptor systems, the extracellular matrix (ECM) molecules laminin and fibronectin have been proposed to function in glial-guided neuronal migration (Liesi, 1985, 1990). Although most immunocytochemical localization experiments suggest that ECM in developing brain is largely restricted to meninges and blood vessels (Hynes, 1990), several studies have provided evidence that ECM is present in migratory pathways. Fibronectin immunoreactivity is localized in the subplate region at the time of subplate cell migration (Stewart and Pearlman, 1987; Chun and Shatz, 1988) and along pathways of granule neuron migration into the external granule cell layer (Hatten et al., 1982). Liesi et al. (1985, 1989) have reported punctate deposits of laminin immunoreactivity along Bergmann glial fibers during the time of granule neuron migration into the internal granule cell layer. Similarly, in the developing chick cerebellum, cytotactin immunostaining is localized to the processes and end-feet of radial glia (Grumet et al., 1985; Chuong et al., 1987). Thus, ECM components may provide receptor systems for glial-guided neuronal migration.

To identify glial membrane receptor systems in CNS neural migration, we have developed a novel, in vitro assay, substituting glass fibers for living glial fibers, and analyzing the mi- 
gratory behavior of granule neurons on these fibers by timelapse video microscopy. In the present experiments, we report that glass fibers coated with astroglial membranes (AM fibers), but not with $3 \mathrm{~T} 3$ cell membranes (3T3M fibers), support granule neuron migration. Among components of the ECM, glass fibers coated with laminin (LAM fibers) support extensive granule cell migration. Antibody perturbation experiments provide evidence that whereas astrotactin promotes neural migration on living glia (Fishell and Hatten, 1991) and AM fibers, the integrin $\beta 1$ receptor system promotes migration along LAM fibers. These findings suggest that multiple receptor systems support CNS neuronal migration.

\section{Materials and Methods}

\section{Preparation of glass fibers}

Individual glass fibers of similar geometry to radial glial fibers $(0.5-2$ $\mu \mathrm{m}$ in width, $>100 \mu \mathrm{m}$ in length) were obtained by shattering Whatman glass fiber filters (no. $1820024,2.4 \mathrm{~cm}$ ). Whole filters were shattered by stirring or vortexing in PBS and single fibers were pelleted by highspeed microcentrifugation for $10 \mathrm{~min}$. Fibers were either uncoated, or coated first with polylysine (100 $\mu \mathrm{g} / \mathrm{ml}$, Sigma) and then coated with either astroglial membranes or $3 \mathrm{~T} 3$ cell membranes (described below), or individual extracellular matrix molecules (laminin, $2.5-500 \mu \mathrm{g} / \mathrm{ml}$; fibronectin, $50-500 \mu \mathrm{g} / \mathrm{ml}$; and collagen IV, $50 \mu \mathrm{g} / \mathrm{ml}$ ) obtained from Collaborative Research. Coating of fibers was accomplished by incubating fibers with these substrates for $2-3 \mathrm{hr}$ at $4^{\circ} \mathrm{C}$.

\section{Preparation of astroglial membranes}

Membranes were prepared by a modification of the method of Brunette and Till (1971) from astroglia harvested from cerebella of postnatal day 3-8 (P3-P8) mice. In brief, cells were homogenized in lysis buffer (20 mM Tris $\mathrm{HCl}, 1 \mathrm{~mm} \mathrm{ZnCl}$, protease inhibitors $1 \mathrm{~mm}$ phenylmethylsulfonyl fluoride, $1 \mu \mathrm{M}$ pepstatin A, $1 \mu \mathrm{g} / \mathrm{ml}$ leupeptin), nuclei were pelleted out by centrifugation $(270 \times g, 5 \mathrm{~min})$, and remaining material was pelleted $(48,200 \times g, 20 \mathrm{~min})$, resuspended, and run on a dextranpolyethylene glycol gradient to isolate purified membrane material. The amount of membrane material obtained was analyzed by Pierce BCA protein assay. Identical methods were used to prepare 3T3 cell membrane material.

To measure the amount of membrane material bound to glass fibers, we determined the amount of membrane material required to saturate the filter. Glial monolayers were incubated with ${ }^{35} \mathrm{~S}$-methionine $(50 \mu \mathrm{Ci} /$ $\mathrm{ml}$; New England Nuclear) in order to label membrane protein, membrancs were preparcd, and varying concentrations of membranc material were spotted onto individual filters. Filters were washed to remove unbound material and then analyzed to determine the amount of radiolabeled membrane protein bound and the level of membrane material required for filter saturation. Subsequently, all fibers cultured with granule neurons were coated with saturating levels of protein. As a second approach to ensure that single fibers were in fact coated with astroglial membrane, we used autoradiography (as described in Streck et al., 1992) to visualize the distribution of ${ }^{35}$ S-labeled membrane protein along single fibers. Immunostaining (as described in Edmondson et al., 1988) with anti-laminin antibodies (Collaborative Research) was used to confirm the presence of laminin immunoreactivity on the laminin fibers we assayed and to visualize laminin expression in tissue sections of $\mathrm{P} 7$ mouse cerebellum.

\section{Purification of granule cells and cell culture procedures}

Granule cells were purified from 3-7-d-old (P3-P7) C57B1/6J mouse cerebellum as described (Stitt and Hatten, 1990). Granule neurons $\left(\sim 1 \times 10^{6}\right.$ cells $/ \mathrm{ml}$ in a final volume of $\left.50 \mu \mathrm{l}\right)$ were cultured with glass fibers in glass coverslip microwells coated with polylysine $(100 \mu \mathrm{g} / \mathrm{ml})$. To provide trophic support, a top coverslip containing astroglial cells was inverted over the microwell. Cultures were grown in Eagle's basal medium (GIBCO) supplemented with horse serum $(10 \%$; GIBCO), glucose ( $8 \mathrm{~mm}$ ), glutamine (30 $\mathrm{mm}$; GIBCO), and penicillin-streptomycin $(20 \mathrm{U} / \mathrm{ml} ; \mathrm{GIBCO})$ and were maintained in a $\mathrm{CO}_{2}$ incubator at $35^{\circ} \mathrm{C}$. After 12-14 hr in vitro, serum-containing medium was replaced by serum-free medium (Fishell and Hatten, 1991) and cultures were ana- lyzed for migration using high-magnification video-enhanced contrastdifferential interference contrast (AVEC-DIC) microscopy.

\section{Video microscopy}

Images of granule neuron migration along glass fibers were obtained with a Hamamatsu $\mathrm{C} 1966$ video camera with a Chalnicon tube mounted on a Zeiss Axiovert 35 microscope equipped with DIC-Nomarski optics (as described in Edmondson and Hatten, 1987). Images were recorded on a Panasonic Memory Disk Recorder, and Universal Imaging IMAGE-1 AT software was used for image processing and motion analysis.

\section{Migration assay}

High $(100 \times)$ magnification was used to examine granule neuron cytology along glass fibers. Migrating neurons were identified by cytological features described previously (Edmondson and Hatten, 1987). For each group of treated fibers [i.e., polylysine-coated fibers (PLYS fibers), etc.], a minimum of three experiments were carried out to screen for the presence of migratory profiles, with a total cell sample of approximately 3000 cells per group. To analyze migration we used a modification of a low-power assay developed by Fishell and Hatten (1991). Briefly, 310 fields per microwell were scribed, labeled, and followed in time-lapse light microscopy at low magnification $(32 \times)$. Migrations of individual neurons within a field were tracked and logged every hour for $2-5 \mathrm{hr}$ using Universal Imaging IMAGE-1 software. For each group of treated fibers (PLYS fibers, etc.), migration assay experiments were conducted a minimum of three times, providing a total sample of 300-600 neurons bound to glass fibers. In cultures where migration profiles were observed, the migration rates of cells expressing migration profiles were quantitated. For cell populations that did not express migration profiles (e.g., cells on PLYS fibers), migration rates for a random population of cells were quantitated.

\section{Antibody perturbation studies}

$A M$ fibers. Using uncoated, rather than polylysine-coated, culture plates reliably increased the number of granule neuron migration profiles we observed using light microscopy. This was necessary to obtain a large enough sample of migration profiles to perform antibody perturbation analyses. Granule neurons were purified (as described), transferred to serum-free medium, and then incubated with either anti-astrotactin, or control (normal rabbit serum), Fab fragments $(1 \mathrm{mg} / \mathrm{ml}$ ) for $30 \mathrm{~min}$ on ice prior to plating. Neurons were then plated in coculture with AM fibers, and additional Fab fragments were added to the microwell to bring the final concentration of Fabs to $1 \mathrm{mg} / \mathrm{ml} ; 12-24 \mathrm{hr}$ later, 40 ficlds from cach culturc condition were examined for the presence of migration profiles using video microscopy. Similar experiments were performed using anti-astrotactin $\mathrm{IgG}(1 \mathrm{mg} / \mathrm{ml})$.

$L A M$ fibers. Polyclonal antisera (1:20 in serum-free medium) to laminin (gift of Dr. L. Liotta of the National Institute of Health, Bethesda, MD), integrin $\beta 1$ (GP140; gift of Dr. C. Buck of the Wistar Institute), or astrotactin $[1: 10$, absorbed against a lung carcinoma cell line, line 1 (Kennel et al., 1989); line 1 cells provided by Dr. E. Marcantonio] were added 1-2 hr postplating to cultures of granule neurons and LAM fibers. Control cultures received normal rabbit serum (1:20); 12-24 hr later all cultures were screened for the presence of migratory profiles.

Mixed cultures of neurons and live astroglia. Cultures of migrating neurons and radially differentiated astroglia were prepared as previously described (Fishell and Hatten, 1991). Polyclonal antisera to laminin (1: 20) were added to cultures of migrating neurons and astroglia $48 \mathrm{hr}$ postplating, and $2 \mathrm{hr}$ later cultures were assayed for migration using the low-magnification assay.

\section{Geometry experiments}

To analyze the contribution of glial fiber geometry to neuronal migration, neurons were plated in the absence of glass fibers, on coverslips coated with polylysine $(100 \mu \mathrm{g} / \mathrm{ml})$ and either laminin $(50 \mu \mathrm{g} / \mathrm{ml})$ or astroglial membranes ( $\sim 800 \mu \mathrm{g} / \mathrm{ml}) ; 12-24 \mathrm{hr}$ later, neuronal migration was analyzed over a $2-5 \mathrm{hr}$ observation period using time-lapse video microscopy.

\section{Fixed glia experiments}

Cultures of migrating neurons and radially differentiated glia were prepared as previously described (Fishell and Hatten, 1991). Forty-eight 
hours postplating, cultures were fixed with aldehydes $(0.5-4 \%)$ and then thoroughly washed with CMF-PBS. PKH26 dye-labeled (Gao et al., 1992) purified living granule neurons in BME plus $10 \%$ horse serum were then added to the fixed cultures, and 12-24 hr later cultures were analyzed for migration of living neurons on fixed glia by high-magnification $\Lambda$ VEC-DIC.

\section{Results}

Previous studies on glial-guided neuronal migration established that migrating neurons express a specialized cytology, including a close apposition to the glial fiber, bipolar shape, extension of a tapered leading process, caudal positioning of the nucleus, and streaming of intracellular vesicles into the leading process (Edmondson and Hatten, 1987; Gregory et al., 1988; Gasser and Hatten, 1990a,b). In the present experiments, to identify glial receptor systems that function in CNS neuronal migration, we developed an assay to analyze the behavior of granule neurons on coated glass fibers.

\section{Granule neurons fail to migrate on glass fibers and PLYS fibers}

To analyze whether glial fiber geometry alone was sufficient to support granule neuron migration, we substituted glass fibers for living astroglia in microcultures of cerebellar granule cells. Individual glass fibers of similar geometry to radial glial fibers (0.5-2 $\mu \mathrm{m}$ in width, $>100 \mu \mathrm{m}$ in length) were obtained from Whatman glass fiber filters and placed in glass coverslip microcultures at a density of approximately 500-750 fibers per well. Granule neurons, purified on P3-P7, were added to wells containing the fibers. By light microscopy, granule cells adhered poorly to untreated glass fibers, with approximately $5 \%$ of the cells bound 12-20 hr after plating. By high-magnification AVECDIC microscopy, granule neurons apposed to glass fibers did not express the specialized cytology characteristic of migrating cells, that is, bipolar shape, caudal positioning of the nucleus, extension of a leading process, and oriented streaming of intracellular vesicles (Edmondson and Hatten, 1987; Gregory et al., 1988). Instead, apposed cells were spherical rather than bipolar, and they extended neurites tipped with growth cones rather than the tapered leading process characteristic of migrating neurons (not shown). To measure cell movement, time-lapse AVEC-DIC images were obtained at low magnification over a 2-5 hr observation period (Fishell and Hatten, 1991). By time-lapse AVEC-DIC microscopy, we did not observe any migration along uncoated glass fibers in a cell sample of approximately 300 neurons (not shown). This suggested that glial fiber geometry alone was not sufficient to support neural migration.

To examine whether glass fibers coated with polyamines, a more adhesive substratum, would support neural migration, we pretreated the fibers with poly-D-lysine. By microscopy, granule neurons bound to PLYS fibers within several hours after plating. When the culture substratum was also treated with polylysine, approximately equal numbers of cells bound to the fibers and to the culture surface, suggesting that the neurons did not bind preferentially to PLYS fibers over a polylysine-coated dish. Neurons that bound to the PLYS fibers tended to clump together, rather than disperse along the fibers. This pattern of cell distribution along PLYS fibers, where neurons tended to bind to each other rather than the fiber, contrasted with that of neurons on living astroglia, where neurons tend to be distributed individually along the length of the glial fiber and bind preferentially to the glial fiber over neighboring neurons (Hatten et al., 1984).
By light microscopy, granule neurons bound to PLYS fibers expressed a round rather than bipolar morphology and extended neurites tipped with growth concs rather than a short, tapered leading process. By time-lapse AVEC-DIC microscopy, none of the cells we monitored in a cell sample of approximately 300 neurons migrated over the course of several hours (Fig. 1). Quantitation of a random cell sample $(N=48)$ on PLYS fibers reveals an average movement rate of $1.09 \mu \mathrm{m} / \mathrm{hr} \pm 0.160( \pm \mathrm{SEM})$. These short, random movements of rounded cells reflect a baseline level of motility of most living cells in culture and are qualitatively different than those movements displayed by migrating neurons. This suggested that, although neurons bound to PLYS fibers as avidly as to a polylysine culture surface, polylysine was not sufficient to support granule neuron migration.

\section{Granule neurons migrate on $A M$ fibers}

To examine whether receptor systems expressed by astroglial fibers were sufficient to support neural migration, we purified astroglial cells from P3-P8 ccrcbcllum (Hattcn, 1985), prepared glial plasma membranes, and coated the fibers with plasma membrane material ( $20 \mu \mathrm{g} / \mathrm{mg}$ filter). Examination of cultures by light microscopy $12-24 \mathrm{hr}$ after plating revealed that approximately $15 \%$ of granule neurons bound to AM fibers. Approximately $3 \%$ of neurons bound to AM fibers expressed migratory profiles, having a bipolar shape and leading process. Plating glass fibers on uncoated, rather than polylysine-coated, glass coverslips resulted in a much higher percentage of migration profiles on AM fibers (see below), presumably because more cells adhered preferentially to AM fibers over the untreated substrate. By AVEC-DIC microscopy, bipolar granule neurons bound to AM fibers migrated on the fibers (Fig. 2). At high magnification, the cytology and the pattern of movement of granule neurons along AM fibers were strikingly similar to that of granule neurons migrating on living astroglial fibers (Fig. 3). Migrating ncurons were closcly apposed to the AM fiber, expressing a bipolar shape and extending a leading process that enfolded the AM fiber. As seen for neurons migrating on intact glia, the nucleus of migrating cells was positioned in the rear of the cell, and intracellular vesicles streamed from the rostral portion of the soma into the leading process. Moreover, as seen for cells migrating along living glia, granule neuron migration on AM fibers was saltatory, consisting of periods of movement interspersed with stationary periods. The mean rate of migration for neurons expressing a migration profile was $5.5 \pm 0.96 \mu \mathrm{m} /$ $\mathrm{hr}(N=17)$, and among cells that moved $10 \mu \mathrm{m} / \mathrm{hr}$ or more, the average rate of migration was $13.38 \pm 3.41 \mu \mathrm{m} / \mathrm{hr}$ (Fig. 4). These rates are slower than, but within the range of, speeds recorded for granule cell migration along living glial fibers (Fishell and Hatten, 1991).

Both the binding and motility of granule neurons along AM fibers depended on the amount of glial membrane protein material that was bound to the fibers. Under conditions where binding of glial membranes was not at saturation levels, granule neurons failed to bind to or migrate along AM fibers. Binding assays of radiolabeled astroglial membrane material revealed that the level of membrane protein required for saturation binding was $20 \mu \mathrm{g} / \mathrm{mg}$ of filter. At saturating levels of membrane, autoradiographic localization showed silver grains corresponding to radiolabeled glial membrane proteins distributed along the length of the glass fiber (Fig. 2).

To examine directly the contribution of glial fiber geometry to neuronal migration on astroglia, we examined the behavior 

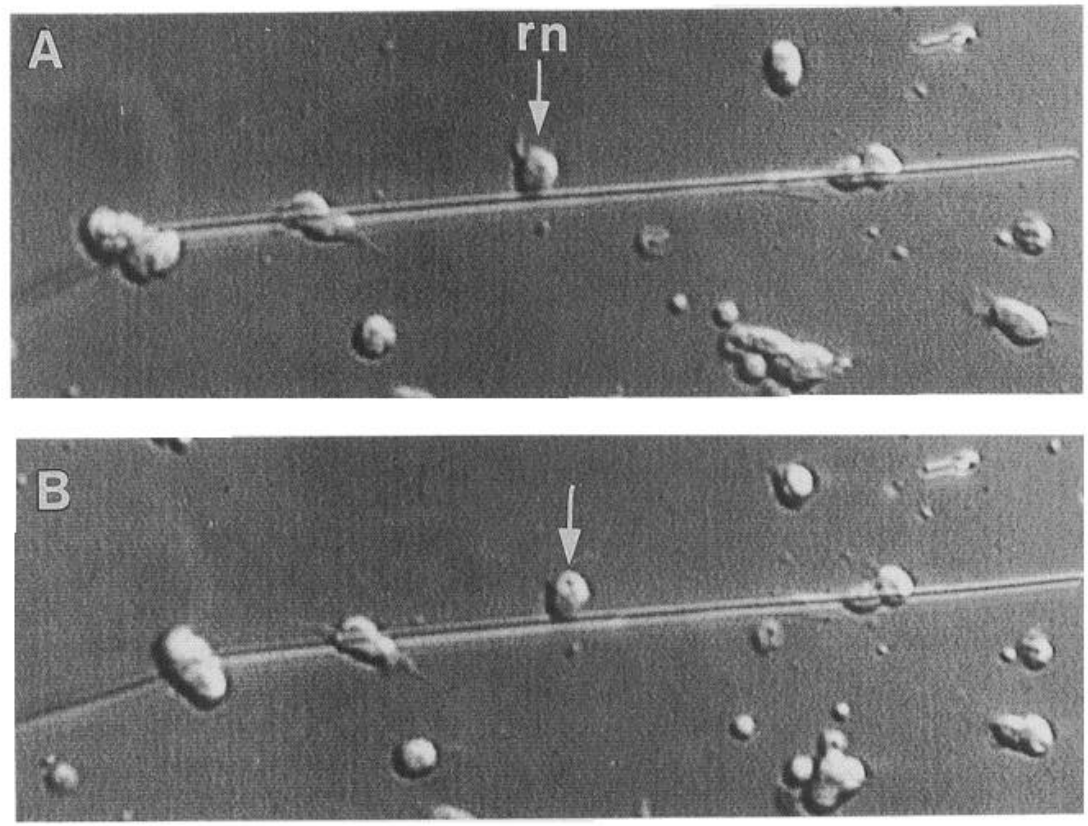

Figure 1. PLYS fibers do not support granule neuron migration. $A$, Single glass fibers of similar dimensions as living glial fibers were coated with polylysine $(100 \mu \mathrm{g} / \mathrm{ml})$ and cultured with granule neurons purified from early postnatal mouse cerebellum. Granule neurons bind to PLYS fibers, but time-lapse video microscopy of the same field 1.5 hr later $(B)$ reveals that granule neurons fail to migrate on these artificial fibers. This suggests that fiber geometry alone is not sufficient to support migration. $C$, High-power video microscopy demonstrates that granule neurons bound to PLYS fibers display a rounded morphology and extend short neurites, a cytology that is characteristic of stationary neurons. $r n$, round neuron; $f$, glass fiber; $n$, neuron. Scale bar: $\sim 34 \mu \mathrm{m}$ for $A$ and $B, \sim 8 \mu \mathrm{m}$ for $C$.

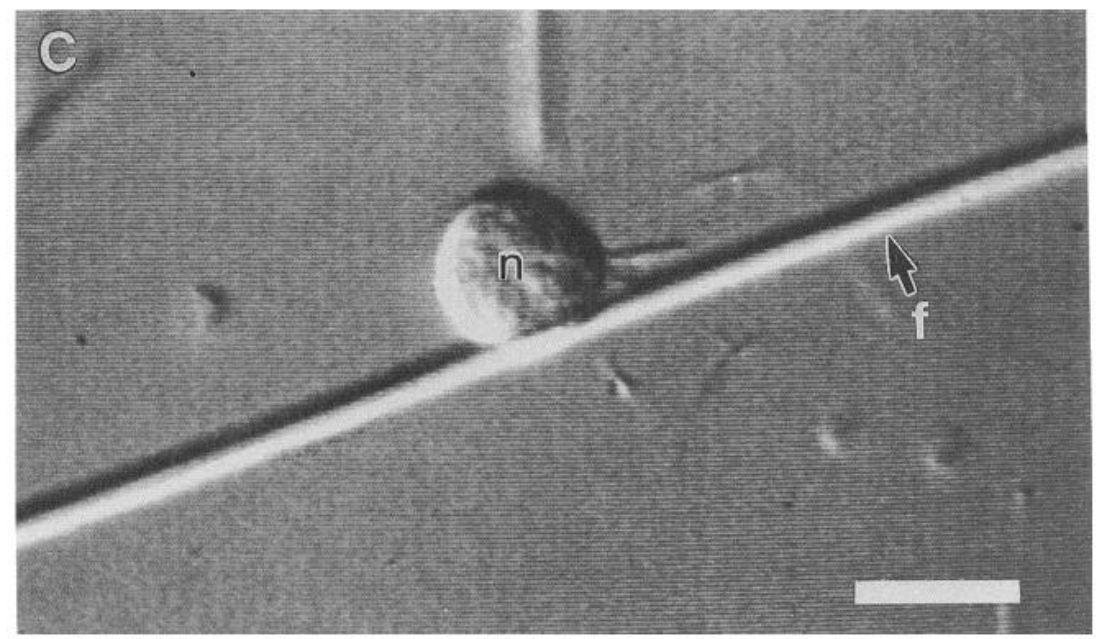

of granule neurons on a large, flat culture surface coated with astroglial membranes. In contrast to results obtained using long, thin glass fibers, neurons plated on a flat surface coated with astroglial membrane had a rounded morphology and failed to migrate over a $3 \mathrm{hr}$ observation period (not shown). This suggests that glial fiber geometry is important for organizing migration cytology and movement along the glial fiber.

\section{Antibody perturbation}

Previous studies have shown that anti-astrotactin antibodies markedly block the binding of granule neurons to astroglial cells (Stitt and Hatten, 1990) and the migration of granule neurons along living glial fibers in vitro (Fishell and Hatten, 1991). To determine whether the astrotactin receptor system functions in neuronal migration along AM fibers, we tested whether antiastrotactin antibodies disrupted the formation of migration profiles by granule neurons on AM fibers. To increase the sample size of migration profiles on AM fibers, glass fibers were plated on uncoated, rather than polylysine-coated, glass coverslip mi- crowells. Examination of fields containing at least one migration profile revealed that in control cultures receiving Fab fragments from normal rabbit serum $(1 \mathrm{mg} / \mathrm{ml}), 46.94 \% \pm 3.96$ of cells bound to AM fibers expressed migration profiles, whereas in anti-astrotactin (Fab fragments, $1 \mathrm{mg} / \mathrm{ml}$ )-treated cultures, $33.83 \% \pm 3.49$ of the cells bound to AM fibers displayed migration profiles. Thus, addition of anti-astrotactin antibodies significantly reduced granule neuron expression of migration profiles by approximately $28 \%$ of control values $(t=2.466 ; p$ $=0.016$; Fig. 5). Addition of anti-astrotactin $\mathrm{IgG}(1 \mathrm{mg} / \mathrm{ml})$ also disrupted migration profile formation to a similar extent $(30 \%$; not shown).

\section{Specificity of granule cell binding to AM fibers}

Binding to $3 T 3 M$ fibers. To examine the specificity of neural migration on AM fibers, we monitored the binding and migratory behavior of granule cells on 3T3M fibers. As reported for glial cells, to measure the amount of $3 \mathrm{~T} 3$ cell membrane material coupled to the fibers, we radiolabeled $3 \mathrm{~T} 3$ cells with ${ }^{35} \mathrm{~S}$-me- 

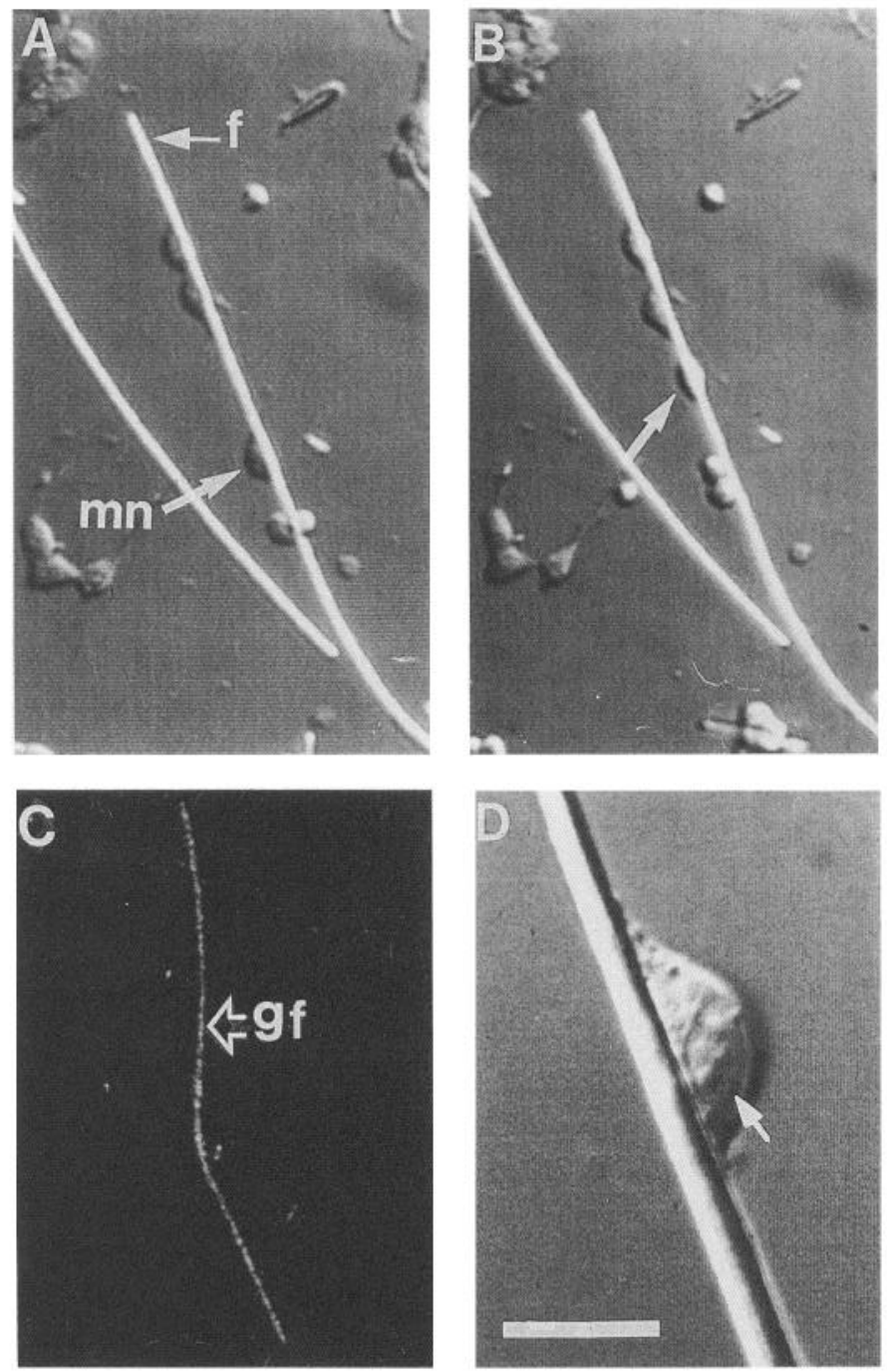

Figure 2. AM fibers support granule neuron migration. A, AM fibers were cultured with granule neurons purified from early postnatal mouse cerebellum. Video microscopy reveals several neurons with migration profiles ( $m n$, migrating neuron) along the length of the glass fiber $(f)$. $B$, Time-lapse analysis of the same field $3 \mathrm{hr}$ later revealed that one neuron (arrow) migrated approximately $21 \mu \mathrm{m}$ along the AM fiber. $C$, Autoradiography reveals that silver grains corresponding to ${ }^{35} \mathrm{~S}$-labeled astroglial membrane proteins are distributed along the length of the glass fiber $(g f) . D$, High-magnification video microscopy reveals that migrating neurons on AM fibers have an elongate bipolar morphology and are attached to the glass fiber along the length of the neuronal soma, and that the nucleus (arrow) is positioned in the rear of the cell. Scale bar: $\sim 40 \mu \mathrm{m}$ for $A$ and $B, 10 \mu \mathrm{m}$ for $D$.

thionine, prepared membrane material, and quantitated the amount of bound membrane by scintillation counting. To examine the distribution of 3T3 membrane labeling along the glass fiber, we carried out autoradiographic localization of radiolabeled membrane material. These experiments demonstrated saturation binding of 3T3 membranes to the fibers and uniform membrane binding along the entire length of all of the fibers we examined (not shown).

When plated in culture wells containing 3T3M fibers, granule cells attached to the fibers, but in contrast to AM fibers where bound neurons expressed a bipolar migratory profile, most neurons bound to $3 \mathrm{~T} 3 \mathrm{M}$ fibers expressed a round, neurite-bearing profile. By low-magnification AVEC-DIC microscopy, the av-
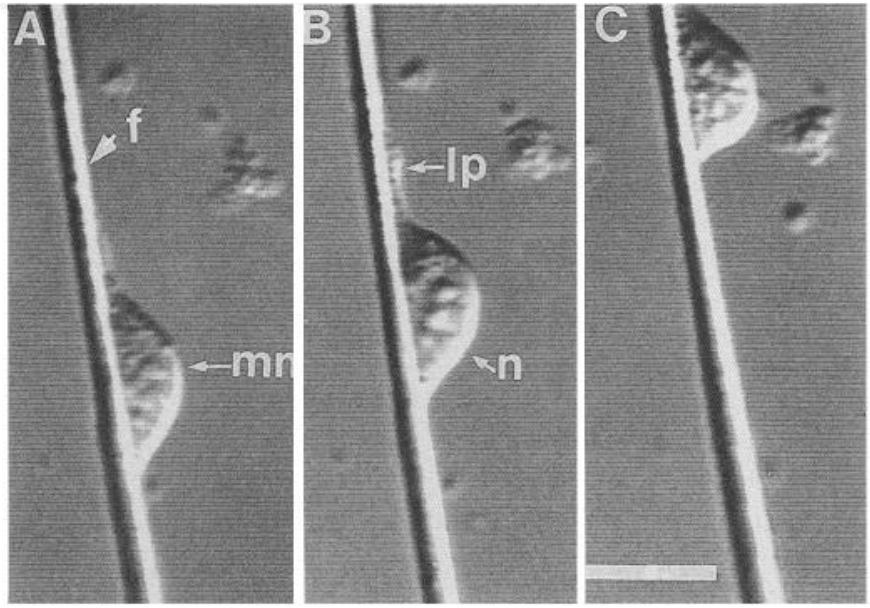

Figure 3. High-magnification time-lapse video microscopy reveals that the cytology and movement dynamics of granule neuron migration along AM fibers are similar to that expressed by neurons migrating on living glia. $A$, Time $=0$ min: migrating neurons $(m n)$ express an elongate morphology, attaching to the glass fiber $(f)$ along the length of the neuronal soma. $B$, Time $=28 \mathrm{~min}$ : as the neuron migrates along the glass fiber, it extends a leading process $(l p)$ and the nucleus $(n)$ is positioned in the rear of the cell, cytological features that are characteristic of neurons migrating along living astroglia. $C$, Time $=133 \mathrm{~min}$ : as the neuron migrates along the fiber, it undergoes cycles of extension and contraction, dynamics that are characteristic of migrating neurons along living astroglia. The distance migrated was approximately $30 \mu \mathrm{m}$ within $133 \mathrm{~min}$. Scale bar, $10 \mu \mathrm{m}$.

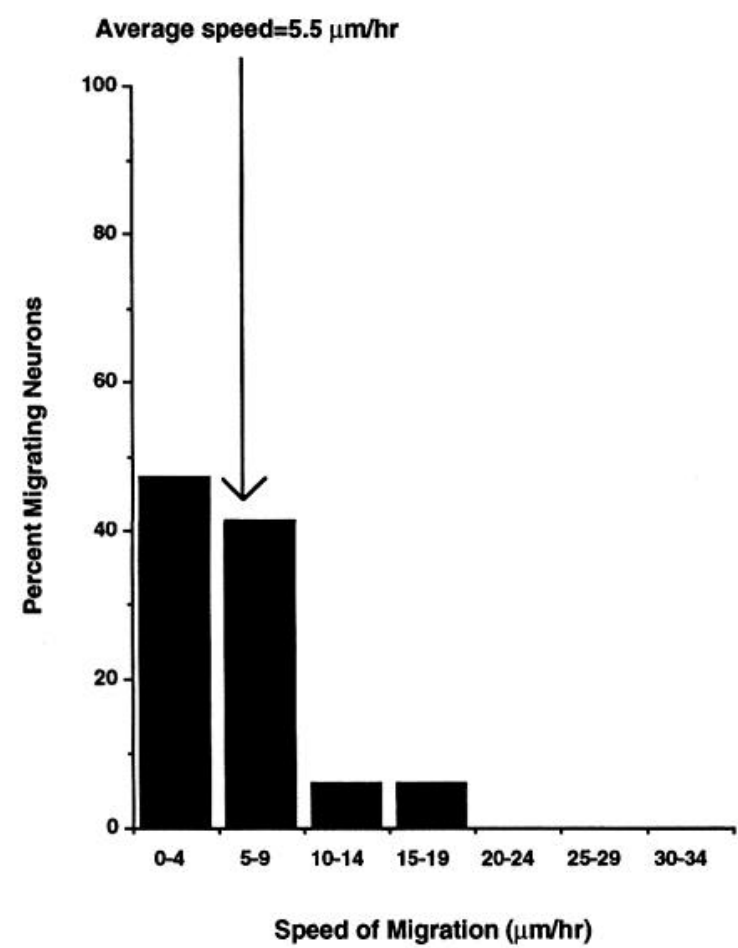

Figure 4. Rate of granule neuron migration on AM fibers. The percentage distribution of migratory rates of a population of granule neurons on AM fibers is shown. Quantitation of migration rates for neurons expressing a migration profile revealed that the mean rate of granule neuron migration was $5.5 \pm 0.96 \mu \mathrm{m} / \mathrm{hr}(N=17)$, with $11 \%$ of the neurons migrating at $10 \mu \mathrm{m}$ or more per hour. These rates were slower than, but within the range of, neuronal migration on living astroglia $(11.79 \pm 0.718 \mu \mathrm{m} / \mathrm{hr} ; N=123$; Fishell and Hatten, 1991). Values are means $\pm \mathrm{SEM} ; N=$ number of cells sampled. 


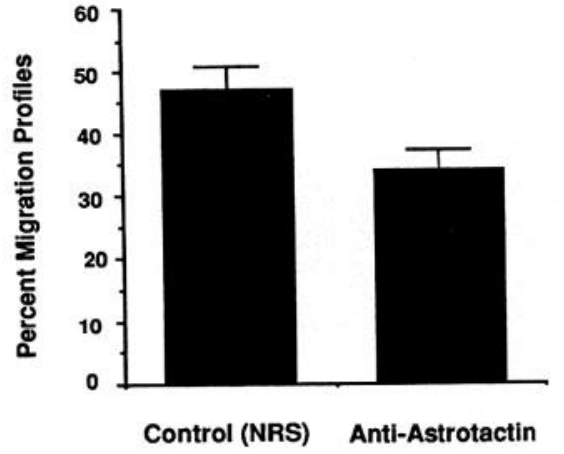

Figure 5. Anti-astrotactin inhibits the expression of migration profiles on AM fibers. Granule neurons from early postnatal cerebellum were incubated with either anti-astrotactin, or control [normal rabbit serum $(N R S)$ ], Fab fragments $(1 \mathrm{mg} / \mathrm{ml})$, and then plated with AM fibers. In control cultures, $46.94 \pm 3.96 \%$ of the neurons bound to AM fibers expressed migration profiles, whereas in anti-astrotactin-treated cultures, the percentage of migration profiles observed was reduced by $28 \%$ of control levels $(t=2.466 ; p=0.016)$. Values are expressed as means from 40 fields; error bars represent the SEM.

erage rate of neuronal migration for a random sample of cells $(N=49)$ was $1.91 \pm 0.305 \mu \mathrm{m} / \mathrm{hr}$ in a $2-5 \mathrm{hr}$ observation period. None of the cells we examined actively migrated, that is, moved $10 \mu \mathrm{m} / \mathrm{hr}$ or more. Thus, granule neurons did not display migratory profiles or migrate along $3 \mathrm{~T} 3 \mathrm{M}$ fibers.

Binding to fixed astroglial cells. As a further control, we examined the behavior of P3-P6 granule cells on killed glial cells, fixing the glia with aldehydes $(0.5-4 \%)$, adding dye-labeled granule cells, and monitoring cell movement as above. Granule neurons failed to migrate on fixed astroglia, but as all of the fixation procedures that we evaluated decreased the binding of radiolabeled granule cell membranes to the glial cells by more than $50 \%$ (Stitt and Hatten, 1990), it was not possible to compare directly the behavior of granule cells on fixed glia with that of granule cells on AM fibers.

\section{Behavior of granule neurons on glass fibers coated with ECM}

To examine whether ECM components shown to support CNS growth cone locomotion would support CNS neural migration, we treated glass fibers with collagen (COLL fibers), fibronectin (FN fibers), or laminin (LAM fibers) and measured neural binding and motility on the fibers. In all cases, to promote the binding of ECM proteins, we pretreated the fibers with polylysine (100 $\mu \mathrm{g} / \mathrm{ml})$.

\section{Collagen IV and fibronectin}

When granule cells were plated onto COLL fibers (collagen IV, $50 \mu \mathrm{g} / \mathrm{ml}$ ), bound cells displayed stationary rather than migratory profiles. Low-magnification AVEC-DIC microscopy of approximately 300 neurons on COLL fibers revealed that only four neurons displayed a bipolar morphology; none of these neurons moved more than $6 \mu \mathrm{m} / \mathrm{hr}$ over a $2-5 \mathrm{hr}$ observation period. The average migration rate of a random sample of cells $(N=42)$ was $1.74 \pm 0.19 \mu \mathrm{m} / \mathrm{hr}$.

When granule cells were plated onto FN fibers, although binding and migratory profiles were observed, the development of migratory profiles was markedly slower than that seen on LAM fibers, requiring as long as $24 \mathrm{hr}$ for the cells to display migratory profiles. After that time period, limited cell migration was observed using low-magnification AVEC-DIC microscopy. Quantitation of a sample of 68 neurons with bipolar profiles revealed
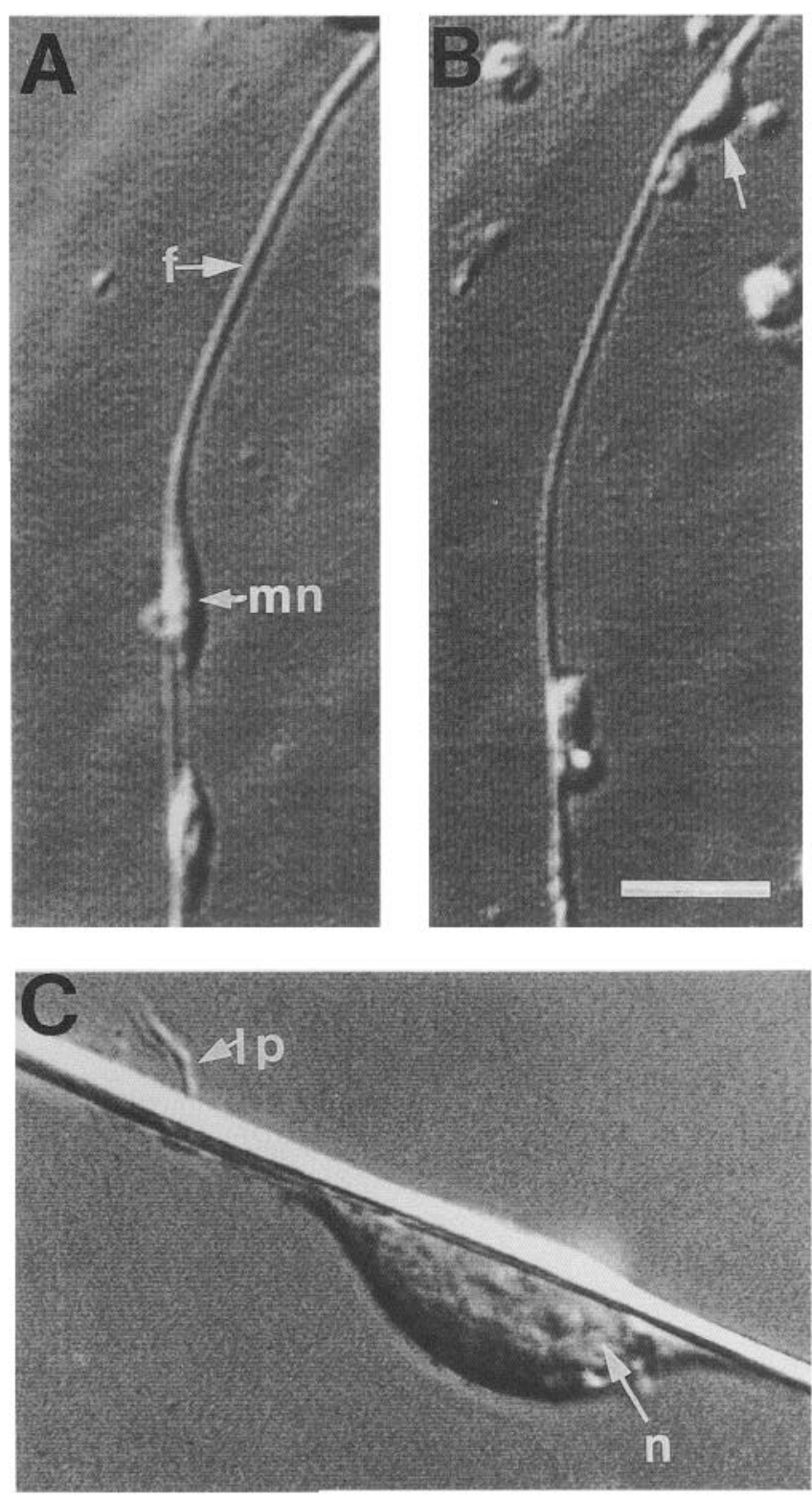

Figure 6. LAM fibers support granule neuron migration. $A$, Granule neurons bind to, and show migration profiles on, LAM fibers $(f ; m n$, migrating neuron). $B$, Time-lapse video analysis of the same field $3 \mathrm{hr}$ later reveals neuronal migration of approximately $80 \mu \mathrm{m}$ (arrow). $C$, High-magnification video microscopy reveals that migrating neurons on LAM fibers express a bipolar morphology, extend a leading process $(l p)$ in the direction of movement, and position the nucleus $(n)$ in the rear of the cell, all of which mimic the cytological features of migrating neurons on living astroglial fibers. Scale bar: $20 \mu \mathrm{m}$ for $A$ and $B, \sim 9$ $\mu \mathrm{m}$ for $C$.

that only approximately $3 \%$ of the neurons migrated more than $10 \mu \mathrm{m} / \mathrm{hr}$. Among neurons migrating more than $10 \mu \mathrm{m} / \mathrm{hr}$, the average rate of migration was $13.8 \pm 0.26 \mu \mathrm{m} / \mathrm{hr}$, and the longest distance traveled was $30 \mu \mathrm{m}$. Increasing the amount of fibronectin $(500 \mu \mathrm{g} / \mathrm{ml})$ used to coat the fiber did not markedly increase the frequency of migratory cells and the distance of migration on FN fibers.

\section{Laminin}

By contrast to results obtained with COLL or FN fibers, granule neurons bound rapidly to LAM fibers. Twelve to twenty-four 

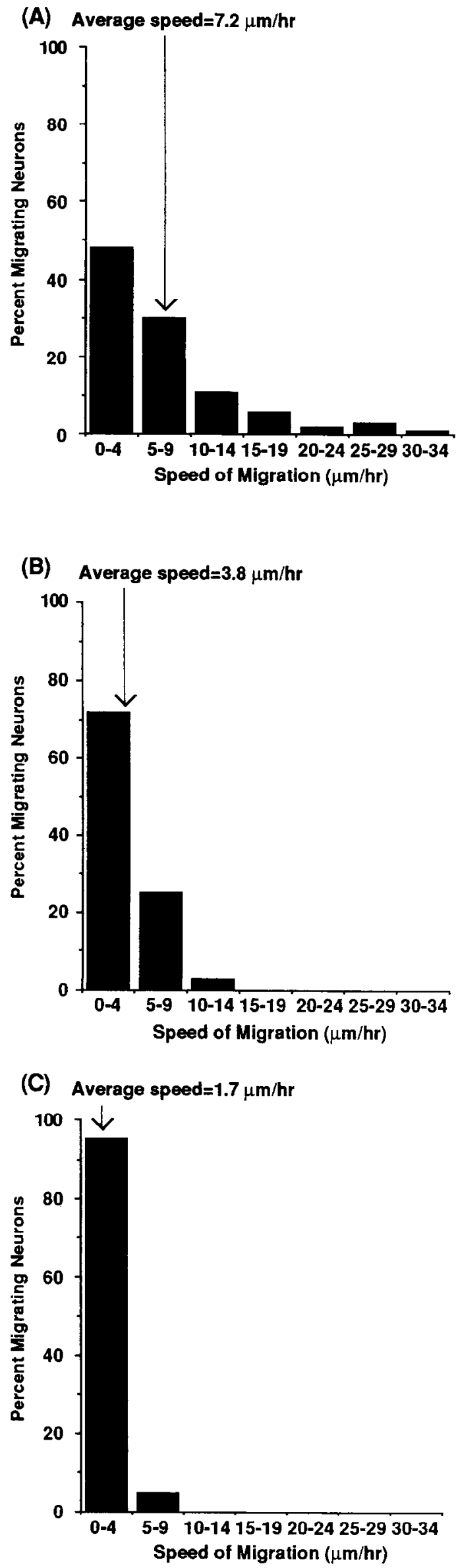

hours postplating, analysis of fields containing 1-15 migration profiles revealed that approximately $65 \%$ of the cells bound to LAM fibers displayed a morphology typical of migratory cells, forming a close apposition with the fiber, expressing a bipolar shape, and extending a leading process along the LAM fiber.

By low-magnification AVEC-DIC microscopy, cell migration was extensive on LAM fibers (Fig. 6), with individual cells moving up to $80 \mu \mathrm{m}$, at rates ranging from 0 to $33 \mu \mathrm{m} / \mathrm{hr}$ within a $2-5 \mathrm{hr}$ observation period. Among neurons expressing a migration profilc $(N=209)$, the mean rate of migration was $7.2 \pm$ $0.437 \mu \mathrm{m} / \mathrm{hr}$ (Fig. 7). Twenty-two percent of the neurons we examined migrated more than $10 \mu \mathrm{m} / \mathrm{hr}$ at an average rate of $17.08 \pm 0.87( \pm$ SEM $) \mu \mathrm{m} / \mathrm{hr}$. These values for the frequency and average speed of neuronal migration on LAM fibers are similar to values reported for granule cell migration on living glia (Fishell and Hatten, 1991). Even at lower concentrations of laminin $(2.5 \mu \mathrm{g} / \mathrm{ml})$, LAM fibers supported granule neuron migration.

By high-magnification AVEC-DIC microscopy, the cytology and dynamics of movement of granule neuron migration along LAM fibers were similar to that observed for granule neurons migrating along living astroglia. Migration was saltatory, with periods of movement interspersed with periods when the neuron paused along the fiber.

To analyze further the role of glial fiber geometry in neuronal migration, we compared the behavior of granule neurons on LAM fibers to cell behavior on a laminin-coated tissue culture dish. Whereas approximately $65 \%$ of the neurons bound to LAM fibers expressed a bipolar morphology characteristic of migrating neurons, granule neurons bound to a laminin-coated dish displayed a wide range of morphologies including a spread motile shape typical of migrating neural crest cells (Newgreen and Thiery, 1980), a rounded, neurite-bearing morphology, and a bipolar, neurite-bearing morphology (not shown). Furthermore, while the mode of movement of migrating neurons on LAM fibers was similar to that observed on living astroglia, a variety of types of cell motility were seen on a laminin surface. This suggests that the contributions of glial fiber geometry to neuronal migration include the organization of the cytology of migrating neurons, orientation of the direction of movement, and regulation of the speed of neural movement.

\section{Antibody perturbation studies}

Anti-laminin antibodies block granule cell binding to LAM fibers. To determine whether the binding and subsequent migration observed on LAM fibers were laminin specific, we tested whether anti-laminin antibodies (1:20) would disrupt binding and

Figure 7. Behavior of granule neurons on glass fibers coated with ECM proteins. The percentage distribution of migration rates of a population of granule neurons on LAM fibers is shown in $A$. LAM fibers supported rapid granule neuron migration, with approximately $22 \%$ of granule neurons that expressed migration profiles migrating more than $10 \mu \mathrm{m} /$ hr $(N=209)$. Among those cells migrating $10 \mu \mathrm{m} / \mathrm{hr}$ or faster, the average rate of migration was approximately $17.08 \pm 0.87 \mu \mathrm{m} / \mathrm{hr}$, and the farthest total unidirectional distance traveled was approximately 80 $\mu \mathrm{m}$. $B$, FN fibers also supported the expression of migration profiles and limited neuronal movement, but was far less effective than LAM fibers. In contrast to their behavior on LAM fibers, only $3 \%$ of neurons we observed $(N=68)$ migrated more than $10 \mu \mathrm{m} / \mathrm{hr}$ on FN fibers, and their average rate of migration was $13.8 \pm 0.26 \mu \mathrm{m} / \mathrm{hr}$. $C$, In contrast, none of the granule neurons we observed migrated (moved $>10 \mu \mathrm{m} /$ hr) on COLL fibers $(N=42)$. $N=$ number of cells sampled. 


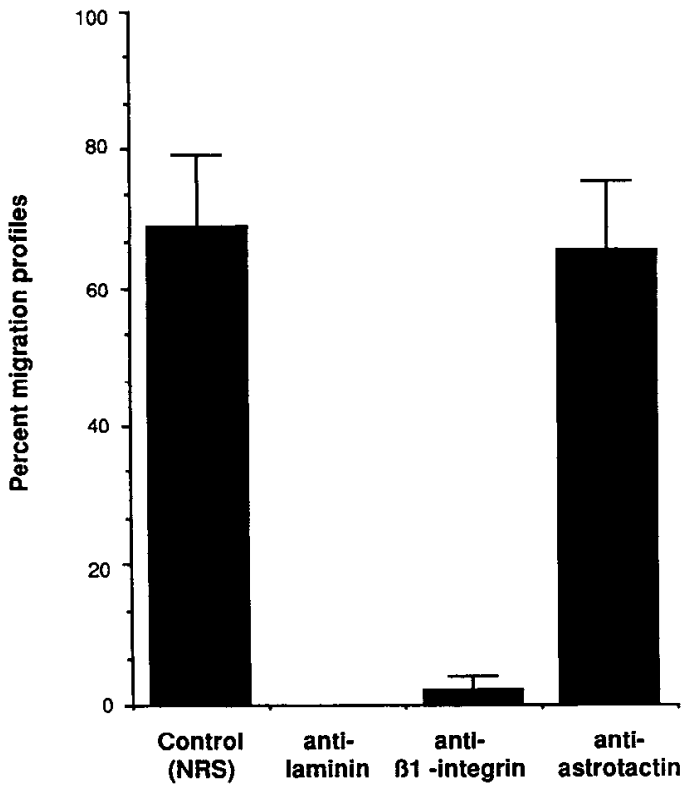

Figure 8. Antibodies to laminin and integrin $\beta 1$, but not astrotactin, block expression of migration profiles on LAM fibers. Antibodies to laminin, integrin $\beta 1$, or astrotactin were added $2 \mathrm{hr}$ postplating to cultures of early postnatal cerebellar granule neurons and LAM fibers. In control cultures, $69 \%$ of the neurons that bound to LAM fibers expressed migration profiles. Antibodies to laminin, or integrin $\beta 1$ dramatically blocked the expression of migratory profiles. In contrast, anti-astrotactin did not significantly disrupt the expression of migratory profiles $(t=$ $0.235 ; p=0.817$ ). Values are expressed as means from 10 randomly selected fields; error bars represent the SEM.

migration of granule neurons on LAM fibers. Addition of antibodies 1-2 hr after the cells were plated induced rapid detachment of the neurons from the LAM fibers. Examination of 10 random fields revealed that none of the neurons apposed to the fiber displayed migratory profiles, whereas in control cultures receiving normal rabbit serum $(1: 20) 68.55 \% \pm 10.44$ of the neurons displayed migration profiles (Fig. 8). This suggested that bound laminin provided the ligand for granule cell binding to and migration along LAM fibers.

By contrast, the addition of anti-laminin antibodies to granule cells in coculture with living glia $48 \mathrm{hr}$ postplating did not disrupt either the binding of neurons to astroglia or the migration of neurons along glial fibers. The average rate of neuronal migration in control cultures was $13 \pm 0.943 \mu \mathrm{m} / \mathrm{hr}(N=60$ neurons), whereas the average rate of migration in anti-laminintreated cultures was $16 \pm 1.29 \mu \mathrm{m} / \mathrm{hr}(N=40$ ncurons; $t=$ $2.061 ; p=0.042)$. Furthermore, in anti-laminin-treated cultures, of the neurons with migratory profiles whose migration rates we measured $(N=40), 77 \%$ migrated $10 \mu \mathrm{m} / \mathrm{hr}$ or faster during a 3.5 hr observation period. In control cultures, approximately $63 \%$ of the cells measured migrated $10 \mu \mathrm{m} / \mathrm{hr}$ or faster during the $3.5 \mathrm{hr}$ observation period. Thus, anti-laminin antibodies did not block the migration of neurons on living astroglia. This suggested that, although laminin supported migration along LAM fibers, it was not a primary receptor system for migration along living glia.

To examine whether the failure of anti-laminin antibodies to perturb migration along living glia related to the level of glial laminin expression, we immunostained tissue sections of P7 mouse cerebellar cortex with anti-laminin antibodies. Immunolocalization of anti-laminin antibodies by the methods used to stain LAM fibers did not demonstrate staining of Bergmann glia or of cerebellar astrocytes. Instead, laminin immunoreactivity was restricted to the meninges and blood vessels (not shown). This suggested that the amount of laminin expressed by living cerebellar glial cells in situ was lower than the amount present on the LAM fibers we assayed.

Anti-integrin $\beta 1$ antibodies block granule cell binding to $L A M$ fibers. Previous experiments demonstrated the expression of integrin $\beta 1$ by granule neurons in vitro (Stitt and Hatten, 1990). To examine the contribution of integrin $\beta 1$ to granule cell binding to LAM fibers, we examined cell binding in the presence of GP140, an anti-integrin $\beta 1$ antibody. The addition of GP140 $(1: 20)$ abolished granule cell binding and therefore the appearance of migratory profiles on LAM fibers. Twenty-four hours postplating we examincd 10 random fields per culture and measured the number of migratory profiles present on a fiber as a percentage of the total number of cells apposed to the fiber. In control cultures receiving normal rabbit serum $(1: 20), 68.55 \%$ \pm 10.44 ( \pm SEM) of neurons apposed to LAM fibers displayed migratory profiles. In contrast, in anti-integrin $\beta 1$ antibodytreated cultures, only $2 \% \pm 2( \pm$ SEM) of the neurons apposed to LAM fibers displayed migratory profiles (Fig. 8), despite the finding there was no significant difference between the two treatment groups in the total number of neurons present per field ( $t$ $=1.234 ; p=0.233$ ). This suggests that integrin $\beta 1$ provides $\mathrm{a}$ neuronal receptor for granule cell binding to LAM fibers.

Anti-astrotactin antibodies do not block migration on LAM fibers. To determine whether the migration of neurons along LAM fibers utilized the neuron-glia ligand astrotactin, we tested whether anti-astrotactin blocked the migration of granule neurons along LAM fibers. Examination of 10 random fields per treatment group revealed that polyclonal antibodies to astrotactin $(1: 10)$ added $2 \mathrm{hr}$ postplating did not significantly block the formation of migratory profiles along LAM fibers; $65.12 \%$ \pm 10.19 of neurons bound to fibers showed migratory profiles in anti-astrotactin-treated cultures compared with $68.55 \% \pm$ 10.44 in control cultures $(t=0.235 ; p=0.817$; Fig. 8). There was no significant difference in the total number of cells present per field between control and anti-astrotactin-treated cultures $(t=1.958 ; p=0.066)$. This suggested that the astrotactin 100 $\mathrm{kDa}$ protein does not provide a neural receptor for laminin.

\section{Discussion}

To identify glial receptor systems that guide neuronal migration, we developed a novel assay to analyze migration on artificial glass fibers in vitro. The present experiments demonstrate that CNS neurons migrate on glass fibers coated with astroglial membranes (AM fibers) and the ECM component laminin (LAM fibers). Antibody perturbation studies reveal that, whereas astrotactin provides a receptor system for neuronal migration on astroglia (Fishell and Hatten, 1991) and AM fibers, the integrin $\beta 1$ receptor system promotes neuronal migration on LAM fibers. These results suggest that multiple receptor systems can support neuronal migration and that glial ligand expression determines which receptor systems function in vivo.

The demonstration that immobilized astroglial membranes support neural migration suggests that astroglial receptor systems, in combination with glial fiber geometry, promote CNS neural migration. A striking aspect of neural migration on AM fibers was the finding that neurons expressed all of the specialized features seen for migrating neurons on intact glial fibers in vivo (Rakic, 1971) and in vitro (Edmondson and Hatten, 1987). 
These features included a bipolar shape, caudal positioning of the nucleus, extension of a leading process along the fiber in the direction of migration, and the oriented flow of cytoplasmic vesicles from the area forward of the nucleus into the leading process. In addition, the dynamics of movement of granule neurons along AM fibers closely resembled those for granule cell migration along living glia. In both cases, a saltatory pattern of movement resulted from cycles of contraction and extension of the cell soma with the neuron repeatedly pausing and sliding forward along the fiber (Edmondson and Hatten, 1987; Hatten and Mason, 1990). The demonstration that granule neurons migrate on AM fibers, and not on fibers coated with $3 \mathrm{~T} 3 \mathrm{mem}$ branes (3T3M fibers), suggests that specific glial membrane components promote CNS neural migration.

Previous studies have demonstrated that anti-astrotactin antibodies block neuron-glia binding (Stitt and Hatten, 1990), and neuronal migration along astroglia in vitro (Fishell and Hatten, 1991). The demonstration that anti-astrotactin inhibits expression of migration profiles on AM fibers is consistent with these results, further demonstrating that astrotactin provides a receptor system for glial-guided neuronal migration.

A persistent question regarding glial guidance in vivo is whether gradients of glial adhesion molecules provide directional cues for migration. Previous in vitro studies demonstrating that single neurons could migrate to the end of a glial fiber, pause, and then migrate in the opposite direction (Hatten et al., 1984) argued against the use of gradients of adhesion molecules as directional cues. The demonstration of CNS neural migration along glass fibers uniformly coated with astroglial membrane material and laminin does not support the conclusion that gradients of adhesion receptor systems orient the direction of neural migration.

The limited number of migrating cells seen on AM fibers was likely due to several factors. First, although we used procedures that generated large sheets of native membrane, some loss of receptor activity is to be expected. Second, the methods we used to couple the membranes to the glass fibers did not necessarily orient the membranes in a native state, so as much as $50 \%$ could have been coupled in an "inside-out" configuration. Finally, since preparation of glial membranes required culturing glial cells in the absence of neurons, conditions where the glia are not differentiated into the radial forms seen to support migration in the developing brain (Hatten, 1985), the membranes we used possibly expressed low amounts of receptor systems present on radial forms of glia. Therefore, it was not unexpected that we observed limited numbers of migrating neurons on AM fibers, that the mean rate of migration was slower on AM fibers than on intact glia, and that antibody perturbation of migration profile expression on AM fibers was somewhat less effective than antibody perturbation of neuronal migration on intact glial fibers (Fishell and Hatten, 1991).

Analysis of the behavior of granule neurons along glass fibers treated with the ECM components (COLL, FN, and LAM fibers) revealed striking differences in the frequency of migration, the average rate of neural migration, and the longest distance traveled by a migratory neuron along ECM components. Among ECM components, laminin promoted frequent, rapid migrations that persisted for $80 \mu \mathrm{m}$ along the glass fiber. Moreover, the cytology of migrating neurons and dynamics of neural movement on LAM fibers closely resembled that of neuronal migration on living astroglia. Fibronectin promoted more limited migration along glass fibers, with neurons migrating at a reduced frequency and slower rate than on LAM fibers. Although granule neurons bound to COLL fibers, cell movement was extremely rare. These results suggest that among ECM components, laminin promotes extensive CNS neural migration. The finding that laminin promotes more frequent migration of granule neurons along FN or COLI, fihers contrasts with results obtained with neural crest migration where both laminin and fibronectin provide a receptor system for cell migration (Perris et al., 1989). The ability of LAM fibers, but not FN fibers, to promote migration is likely to result from the expression of specific heterodimers of integrin $\alpha$ and $\beta$ subunits by immature granule neurons, since studies on fibroblast motility have shown that among $\beta 1$ integrins, expression of particular $\alpha$-subunit can confer motility (Schiro et al., 1991).

The rapid detachment of $95 \%$ of the granule neurons bound to LAM fibers after addition of anti-laminin antibodies or antibodies to the neural laminin receptor integrin $\beta 1$ (Bozyczko and Horwitz, 1986; Ignatius and Reichardt, 1988) suggests that integrin $\beta 1$ was the primary receptor system in neuronal binding to LAM fibers. These studies suggest that the intcgrin $\beta 1$ neural receptor system is sufficient to support neural migration under conditions where laminin is expressed on the glial fiber. By contrast, antibody perturbation studies, using the anti-laminin antibodies that inhibited neural migration along LAM fibers, did not support a role for laminin in neural migration along living, cerebellar glial cells. This result is consistent with the results of Schachner and colleagues, who showed that anti-laminin antibodies fail to disrupt the formation of the internal granule cell layer in a tissue explant assay system (Antonicek et al., 1987). Moreover, although some studies have reported expression of laminin along Bergmann glial fibers in vivo (Liesi, 1985; Liesi and Risteli, 1989), immunostaining of early postnatal cerebellar tissue with the anti-laminin antibodies we used was restricted to meninges and blood vessels. These results suggest that ES laminin does not provide a receptor system for granule cell migration in the developing mousc ccrcbcllar cortex. Our findings do not exclude the possibility that other forms of laminin, including homologs of the laminin A (Ehrig et al., 1990) or B chain (Hunter et al., 1989) specifically expressed in brain, function in neural migration along glial fibers.

In the case of granule cell migration along living glial fibers, antibody perturbation experiments provide evidence that antibodies against the laminin receptor integrin $\beta 1$ do nol reduce the rate of neuronal migration along living cerebellar glial fibers (Fishell and Hatten, 1991). The conclusion that integrin $\beta 1$ does not provide the primary receptor system for glial-guided neuronal migration is supported by our finding that the binding of granule cell membranes to astroglial fibers occurs in the presence of anti-integrin $\beta 1$ antibodies and in the absence of calcium (Stitt and Hatten, 1990). Thus far, among the receptor systems analyzed by antibody perturbation assays in vitro, astrotactin appears to provide a dominant reccptor system for neural migration along glial fibers. Anti-astrotactin antibodies block the binding of granule cell membranes to astroglia (Stitt and Hatten, 1990) and inhibit the migration of living granule neurons along astroglial fibers by $60-70 \%$ in vitro (Fishell and Hatten, 1991).

The failure of antibodies against astrotactin to reduce neuronal binding to LAM fibers suggests that ES laminin does not provide a receptor for astrotactin. At present, the glial receptor(s) for astrotactin is unknown. The finding that two different neural receptor systems can support granule cell migration, astrotactin on living glia and AM fibers, and integrin $\beta 1$ in the LAM fiber system, suggests that multiple receptor systems can function in 
neural migration. The low levels of expression of laminin seen on cerebellar astroglial fibers suggest that this system is not utilized in vivo. The conclusion that multiple receptor systems support granule cell migration along glass fibers is in agreement with observations on growth cone locomotion along glial substrates, where integrins, neural cell adhesion molecules, and cadherins have been shown to promote neurite extension (Chang et al., 1987; Neugebauer et al., 1988; Tomaselli et al., 1988; Reichardt et al., 1989; Elkins et al., 1990). They are also consistent with studies on fibroblast locomotion on ECM components, which provide evidence that multiple receptor systems, including specific heterodimers of integrin $\alpha$ and $\beta$ subunits (Schiro et al., 1991), function in fibroblast motility.

In addition to providing an assay for receptor systems that function in ncural migration, the glass fiber system provided an opportunity to examine the contribution of glial fiber geometry to neural migration. Our results suggest that glial fiber geometry is an important determinant of migration cytology, and mode and orientation of movement. Granule neurons on AM or LAM fibers displayed a bipolar cytology similar to that described for migrating neurons on living astroglial fibers (Edmondson and Hatten, 1987) and that described for neural migration in vivo (Rakic, 1971). The migration of neurons along glial fibers appears to represent a highly specialized form of cell motility, which relies on contraction of a cortical ring of actin to generate a saltatory pattern of extension and retraction of the cell soma along the fiber (Rivas et al., 1991). In contrast to their behavior on a long, thin glass fiber, granule neurons plated on a flat culture surface coated with astroglial membrane displayed a rounded morphology rather than a migration profile, and failed to $\mathrm{mi}$ grate. The contribution of glial fiber geometry to migration cytology and mode of movement was also evident when comparing cell behavior on LAM fibers to cell motility on a laminincoated coverslip. On LAM fibers, the majority of neurons expressed a bipolar shape and migrated with a cadence and speed comparable to that observed on living astroglia. On a laminin coverslip, two forms of movement predominated: fibroblastlike movements of neural cells that were spread on the substratum, possibly representing immature EGL cells, and growth cone locomotion of granule cells undergoing neural differentiation. Thus, the geometry of the glial fiber, reproduced in vitro by an artificial glass fiber, together with specific receptor systems, appeared to induce neural motility resembling glia-guided neural migration.

These experiments provide evidence that CNS neural migrations are controlled by the coordinated expression of specific neural receptor systems and ligand systems along migratory pathways. In the PNS, where the neural crest cell population migrates along a pathway rich in the ECM components laminin and fibronectin, the heterodimers of integrin $\beta 1$ provide the dominant neural receptor for migration. In developing brain, the glial fiber system constrains neural migrations to generate a radial dispersion pattern. The present experiments provide evidence that the geometry of the glial fiber, in combination with specific receptor systems, organizes a specialized form of cell motility that differs from neural crest motility. Although the ECM component ES laminin can support neural migration via utilization of the integrin $\beta 1$ receptor system, the low level of expression of ES laminin on living, cerebellar glial fibers in vivo suggests that this mechanism is not a primary guidance system in situ. On living glial fibers, the astrotactin $100 \mathrm{kDa}$ peptide provides a primary neural receptor system for neuron-glia ad- hesion during the developmental period when migration is ongoing in vivo.

\section{References}

Antonicek H, Persohn E, Schachner M (1987) Biochemical and functional characterization of a novel neuron-glia adhesion molecule that is involved in neuronal migration. J Cell Biol 104:1587-1595.

Bozyczko D, Horwitz. AF (1986) The participation of a putative cell surface receptor for laminin and fibronectin in peripheral neurite extension. J Neurosci 6:1241-1251.

Brunette DM, Till JE (1971) $\Lambda$ rapid method for the isolation of $L$-cell surface membranes using an aqueous two-phase polymer system. J Membr Biol 5:215-224.

Chang S, Rathjen FG, Raper JA (1987) Extension of neurites on axons is impaired by antibodies against specific neural cell surface glycoproteins. J Cell Biol 104:355-362.

Chun JJM, Shatz CJ (1988) A fibronectin-like molecule is present in the developing cat cerebral cortex and is correlated with subplate neurons. J Cell Biol 106:857-872.

Chuong CM, Crossin KL, Edelman GM (1987) Sequential expression and differential function of multiple adhesion molecules during the formation of cerebellar cortical layers. J Cell Biol 104:331-342.

Edmondson JC, Hatten ME (1987) Glial-guided granule neuron migration in vitro: a high-resolution time-lapse video microscopic study. J Neurosci 7:1928-1934.

Edmondson JC, Liem RKH, Kuster JE, Hatten ME (1988) Astrotactin: a novel neuronal cell surface antigen that mediates neuron-astroglial interactions in cerebellar microcultures. J Cell Biol 106:505-517.

Ehrig K, Leivo I, Argraves WS, Ruoslahti E, Engvall E (1990) Merosin, a tissue-specific basement membrane protein, is a laminin-like protein. Proc Natl Acad Sci USA 87:3264-3268.

Elkins T, Zinn K, McAllister L, Hoffmann FM, Goodman CS (1990) Genetic analysis of a Drosophila neural cell adhesion molecule: interaction of fasciclin I and Abelson tyrosine kinase mutations. Cell 60:565-575.

Fishell G, Hatten ME (1991) Astrotactin provides a receptor system for CNS neuronal migration. Development 113:755-765.

Gao WQ, Liu XL, Hatten ME (1992) The weaver gene encodes a nonautonomous signal for CNS ncuronal differcntiation. Ccll 68:841854.

Gasser UE, Hatten ME (1990a) CNS neurons migrate on astroglial fibers from heterotypic brain regions in vitro. Proc Natl Acad Sci USA $87: 4543-4547$.

Gasser UE, Hatten ME (1990b) Neuron-glia interactions of developing rat hippocampal cells in vitro: glial-guided neuronal migration and neuronal regulation of glial differentiation. J Neurosci 10:12761285.

Gregory WA, Edmondson JC, Hatten ME, Mason CA (1988) Cytology and neuron-glial apposition of migrating cerebellar granule cells in vitro. J Neurosci 8:1728-1738.

Grumet M, Hoffman S, Crossin KL, Edelman GM (1985) Cytotactin, an extracellular matrix protein of neural and non-neural tissues that mediates glia-neuron interaction. Proc Natl Acad Sci USA 82:80758079.

Hatten ME (1985) Neuronal regulation of astroglial morphology and proliferation in vitro. J Cell Biol 100:384-396.

Hatten ME (1990) Riding the glial monorail: a common mechanism for glial-guided migration in different regions of the developing brain. Trends Neurosci 13:179-187.

Hatten ME, Mason CA (1990) Mechanisms of glial-guided neuronal migration in vitro and in vivo. Experientia 46:907-916.

Hatten ME, Furie MB, Rifkin DB (1982) Binding of developing mouse cerebellar cells to fibronectin: a possible mechanism for the formation of the external granular layer. J Neurosci 2:1195-1206.

Hatten ME, Liem RKH, Mason CA (1984) Two forms of cerebellar glial cells interact differently with neurons in vitro. J Cell Biol 98:193204.

Hunter DD, Shah V, Merlie JP, Sanes JR (1989) A laminin-like adhesive protein concentrated in the synaptic cleft of the neuromuscular junction. Nature 338:229-234.

Hynes R (1990) Fibronectins, pp 37-42. New York: Springer.

Ignatius MJ, Reichardt LF (1988) Identification of a neuronal laminin receptor: an $M_{r} 200 \mathrm{~K} / 120 \mathrm{~K}$ integrin heterodimer that binds laminin in a divalent cation-dependent manner. Neuron 1:713-725. 
Kennel SJ, Foote LJ, Falcioni R, Sonnenberg A, Stringer CD, Crouse C, Hemler ME (1989) Analysis of the tumor-associated antigen TSP180. J Biol Chem 264:15515-15521.

Liesi $\mathbf{P}$ (1985) Do neurons in the vertebrate CNS migrate on laminin? EMBO J 4:1163-1170.

Liesi P (1990) Extracellular matrix and neuronal movement. Experientia 46:900-907.

Liesi P, Risteli L (1989) Glial cells of mammalian brain produce a variant form of laminin. Exp Neurol 105:86-92.

Miale IL, Sidman RL (1961) Autoradiographic study of cell migration during histogenesis of cerebral cortex in the mouse. Nature 192:766768.

Misson JP, Takahashi T, Caviness VS Jr (1991) Ontogeny of radial and other astroglial cells in murine cerebral cortex. Glia 4:138-148.

Neugebauer K, Tomaselli KJ, Lilien J, Reichardt LF (1988) N-cadherin, NCAM, and integrins promote retinal neurite outgrowth on astrocytes in vitro. J Cell Biol 107:1177-1187.

Newgreen D, Thiery JP (1980) Fibronectin in early avian embryos: synthesis and distribution along the migration pathways of neural crest cells. Cell Tissue Res 211:269-291.

Perris R, Paulsson M, Bronner-Fraser M (1989) Molecular mechanisms of avian neural crest cell migration on fibronectin and laminin. Dev Biol 136:222-238.

Rakic P (1971) Neuron-glia relationship during granule cell migration in developing cerebellar cortex. A Golgi and electron microscopic study in Macacus rhesus. J Comp Neurol 141:283-312.

Rakic P (1972) Mode of cell migration to the superficial layers of fetal monkey neocortex. J Comp Neurol 145:61-84.

Rakic P, Sidman RL (1973) Weaver mutant mouse cerebellum: defective neuronal migration secondary to abnormality of Bergmann glia. Proc Natl Acad Sci USA 70:240-244.
Ramon y Cajal S (1889) Sobre las fibras nerviosas de la capa granulosa del cerebelo. Rev Trim Histol Norm Pathol, nos. 3 and 4.

Ramon y Cajal S (1911) Histologie du systeme nerveux de l'homme et des vertebres. Paris: Maloine. Reprint. Madrid: Consejo Superior de Investigaciones Cientificas, 1955.

Reichardt LF, Bixby JL, Hall DE, Ignatius MJ, Neugebauer KM, Tomaselli KJ (1989) Integrins and cell adhesion molecules: neuronal receptors that regulate axon growth on extracellular matrices and cel surfaces. Dev Neurosci 11:332-347.

Schiro JA, Chan BMC, Roswit WT, Kassner PD, Pentland AP, Hemler ME, Eisen AZ, Kupper TS (1991) Integrin $\alpha^{2} \beta 1$ (VLA-2) mediates reorganization and contraction of collagen matrices by human cells. Cell 67:403-410.

Sidman RL, Rakic P (1973) Neuronal migration with special reference to developing human brain: a review. Brain Res 62:1-35.

Sotelo C, Changeux P (1974) Bergmann fibers and granule cell migration in the cerebellum of homozygous weaver mutant mouse. Brain Res 77:484-491.

Stewart GR, Pearlman AL (1987) Fibronectin-like immunoreactivity in the developing cerebral cortex. J Neurosci 7:3325-3333.

Stitt TN, Hatten ME (1990) Antibodies that recognize astrotactin block granule neuron binding to astroglia. Neuron 5:639-649.

Streck RD, Wood TL, Hsu MS, Pintar JE (1992) Insulin-like growth factor I and II and insulin-like growth factor binding protein-2 RNAs are expressed in adjacent tissues within rat embryonic and fetal limbs. Dev Biol 151:586-596.

Tomaselli KJ, Neugebauer KM, Bixby JL, Lilien J, Reichardt LF (1988) $\mathrm{N}$-cadherin and integrins: two receptor systems that mediate neuronal process outgrowth on astrocyte surfaces. Neuron 1:33-43. 